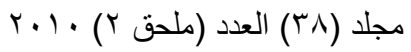
(ISSN 1815-316X)
مجلة زر اعة الر افدين

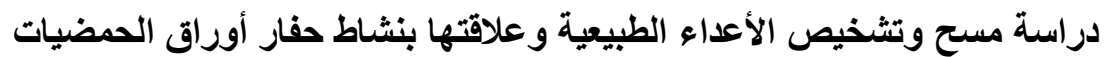 دو وتأثير بعض و المعاملات الكيميائية في المتطفل السائد Ratzeburgiola Incompleta (Poueek)

\author{
ز هر اء عبد المعطي الغضبان \\ كلية الزر اعة ـ جامعة بغداد ـ قسم وقاية النبات
}

\section{الخلاصة}

اظهر مسح للمتطفلات في مكان تنفيذ التجارب ان هناك اربعة انواع من المتطفلات التي تعود للعائلة

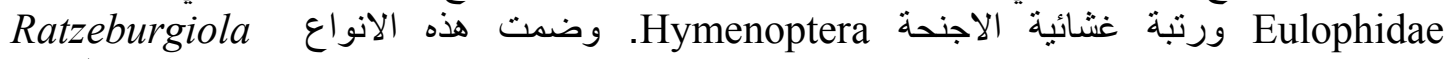

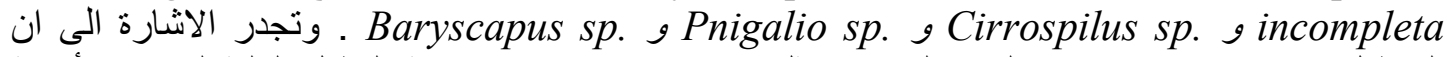

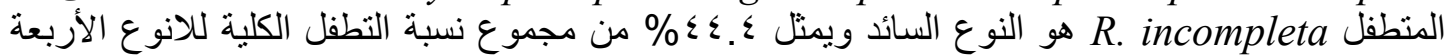

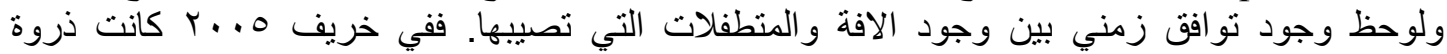

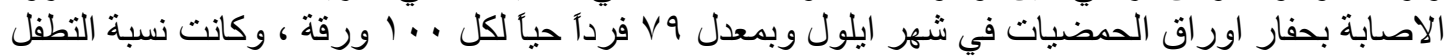

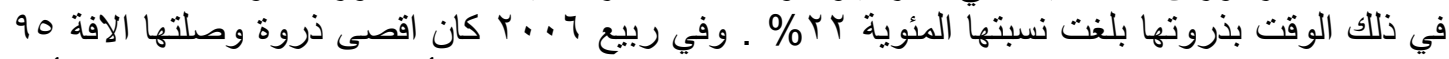

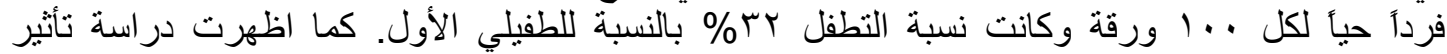

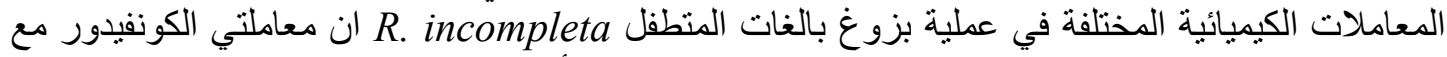

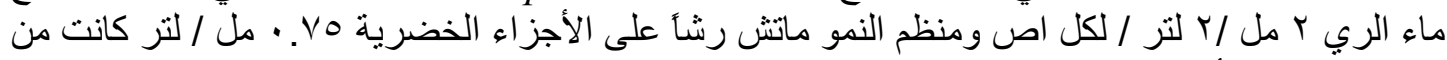

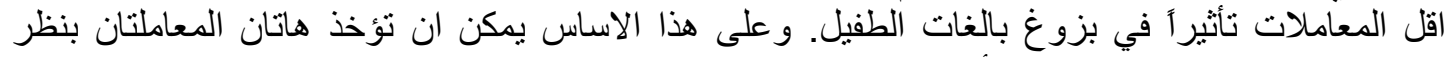

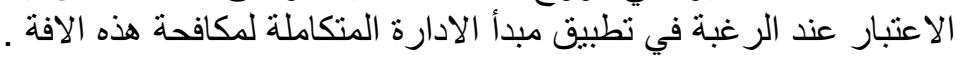

\section{المقدمة}

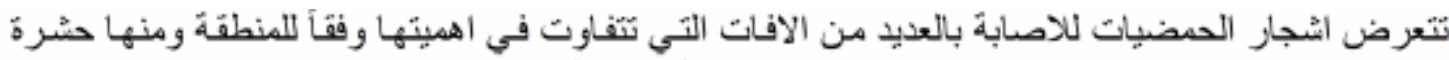

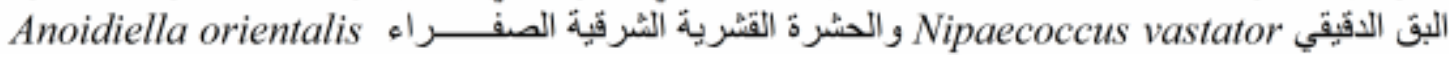
و انو اع الحلم التابعة للاجناس Tetranychus و وذبابة الياسمين البيضاء Eutetranychus واء

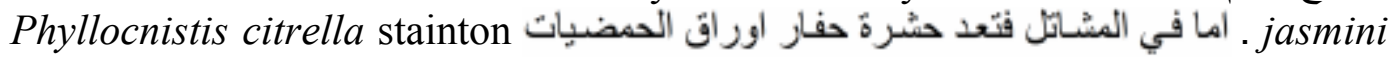

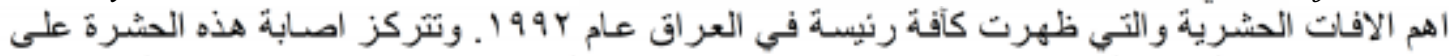

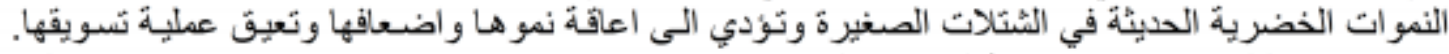

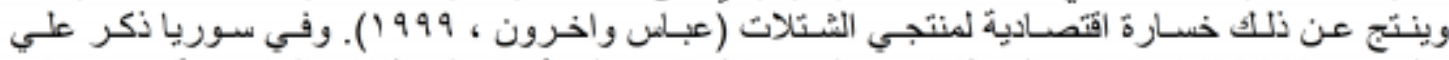

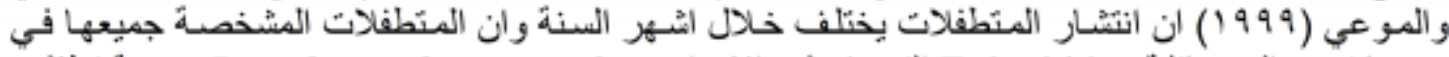

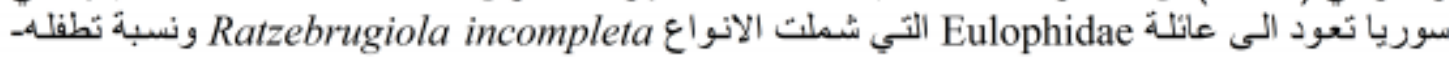

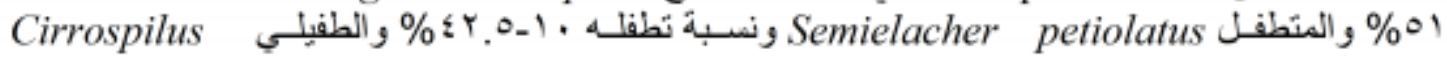

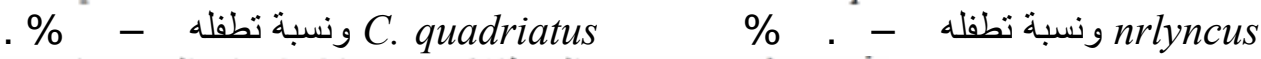

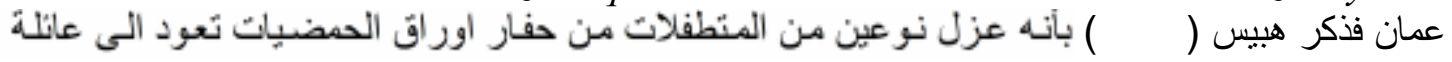
Citrostichus phyllocnist Cirrospilus quadristrialus $\quad$ Eulophidae

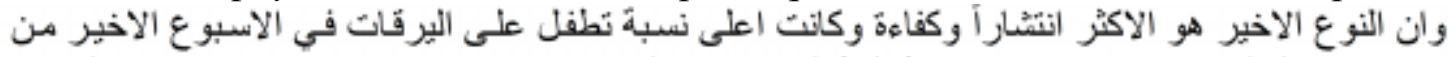

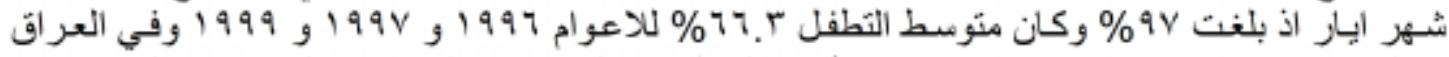

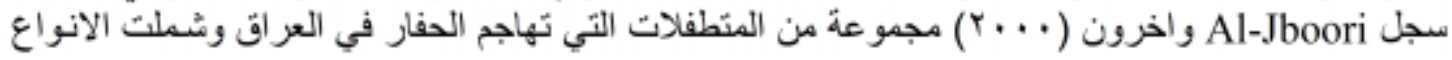
Neochrysocharis sp. Pnigalio sp. Cirrospilus sp. Ratzburgida incompleta ( David

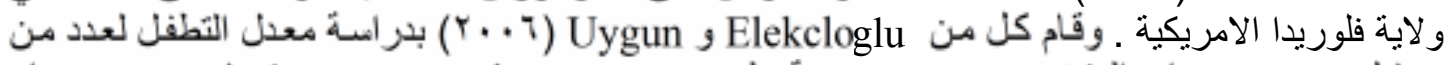

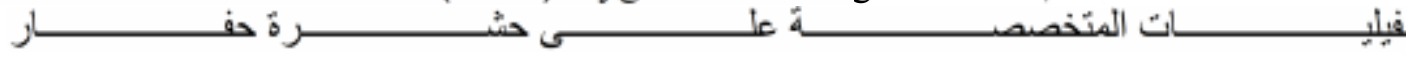




\begin{tabular}{|c|c|}
\hline() & (ISSN 1815-316X) \\
\hline
\end{tabular}

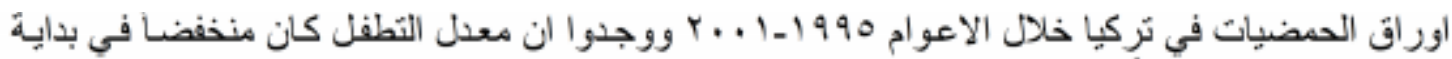

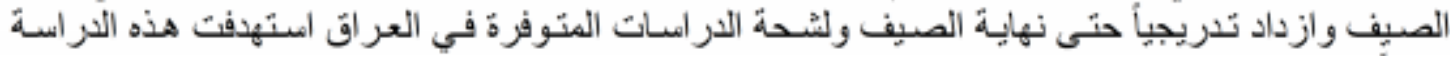
تقييماً لبعض الوسائل اللازمة للحد من اضرار هذه الحشرة في مشاتل الحمضيات في العراق.

\section{مواد البحث وطرائقه}

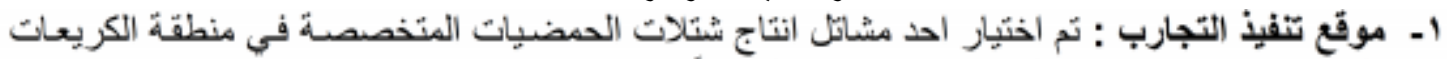

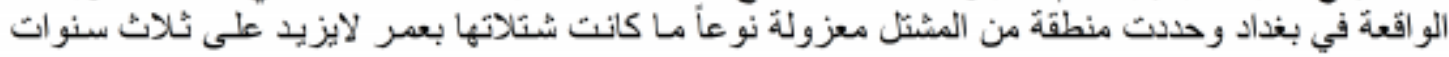

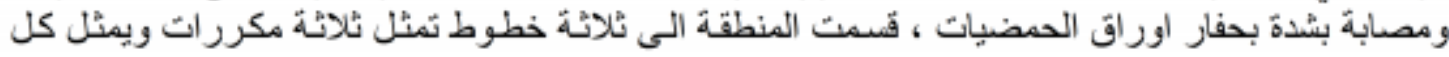

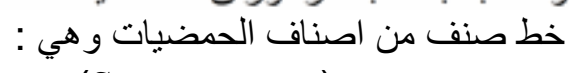

Citrus sinensis (Sweet orange)

C. reticulate (Mandarine)
C. aurantium (Sour orange)

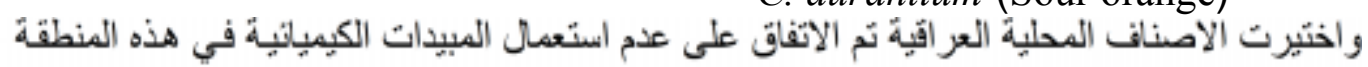

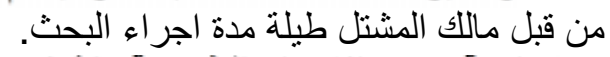

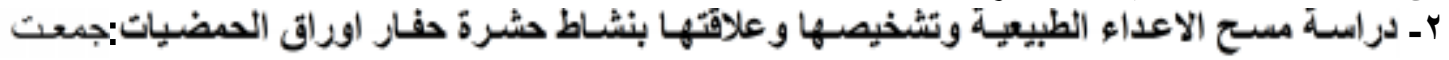

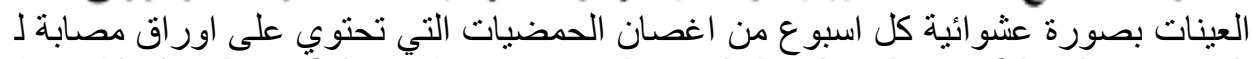

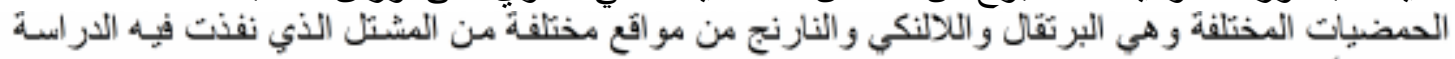

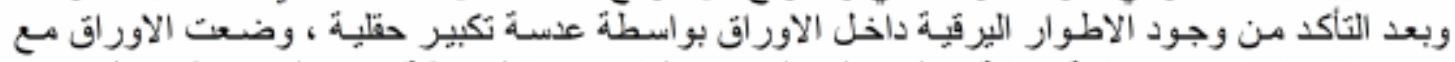

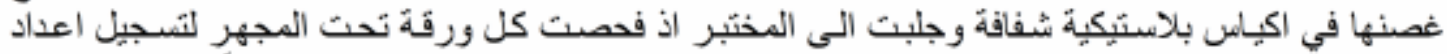

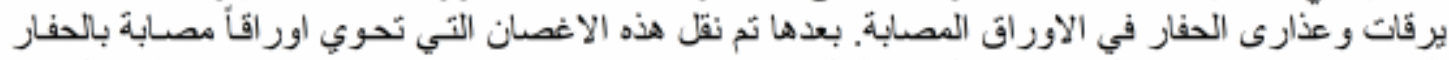

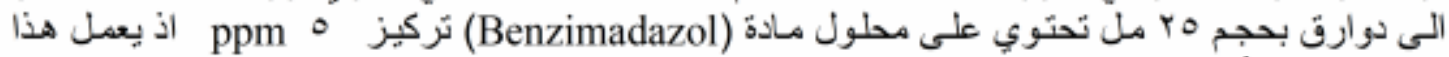

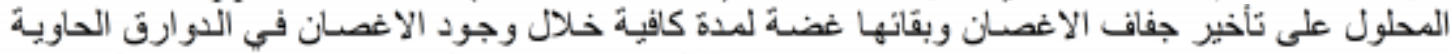

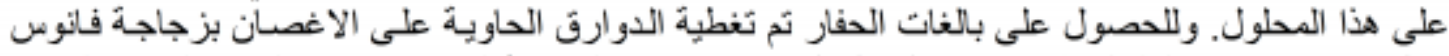

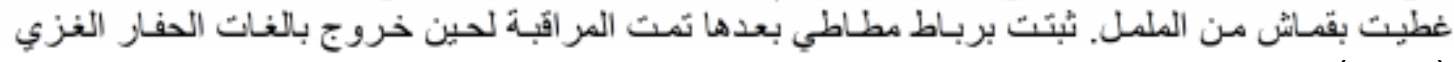

عزلت الاوراق المحتوية على اطوار الافة والتي تظهر عليها علامات التطفل اذ وضعت كل وقد ورقة في

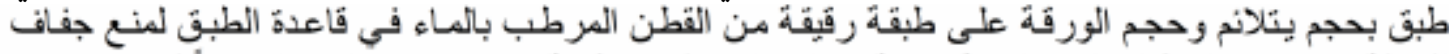

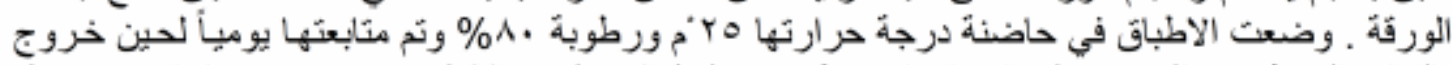

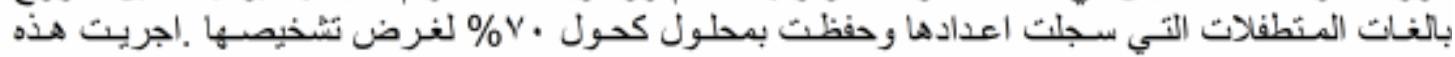

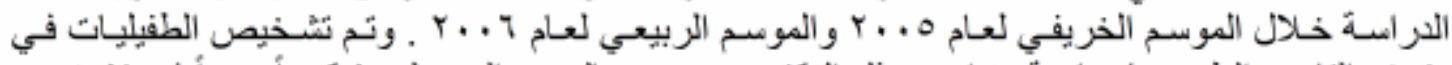

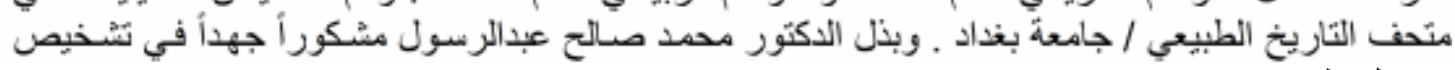
هذه المتطفلات.

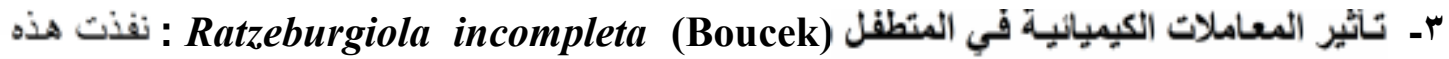

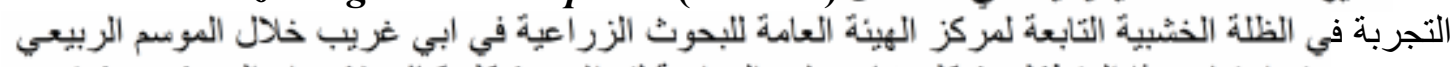

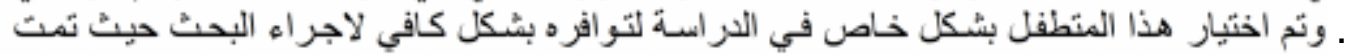

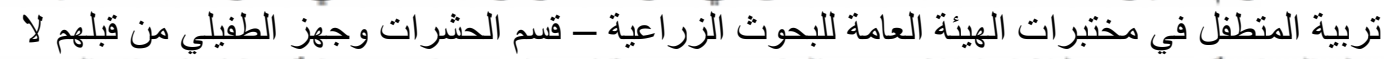

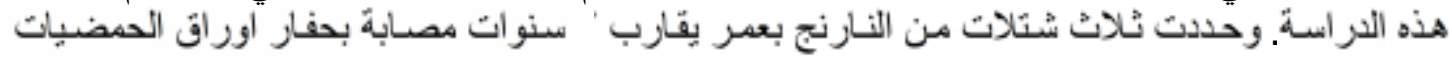

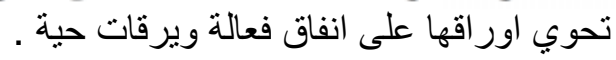

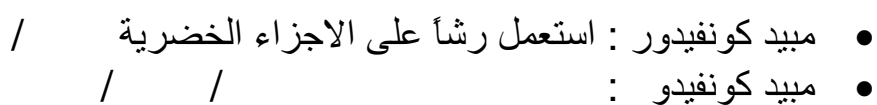

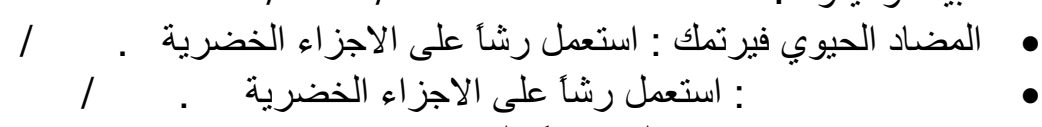

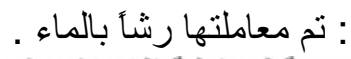

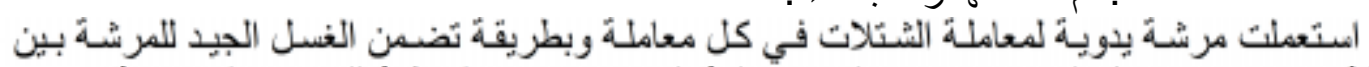

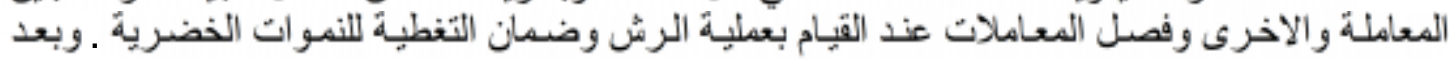




\begin{tabular}{|c|c|}
\hline() & (ISSN 1815-316X) \\
\hline
\end{tabular}

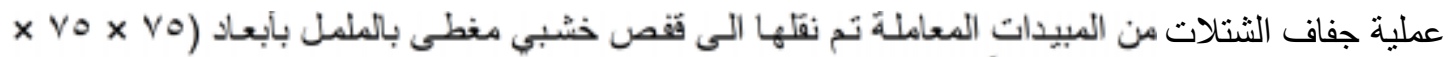

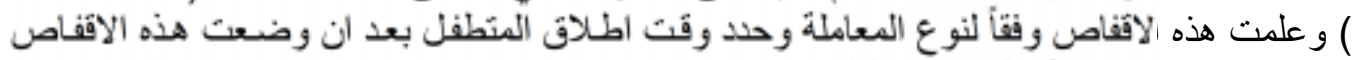

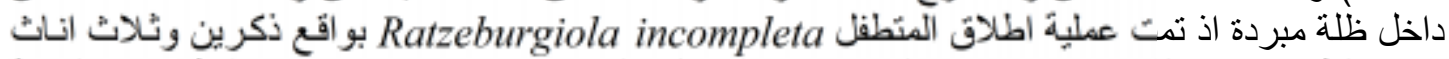

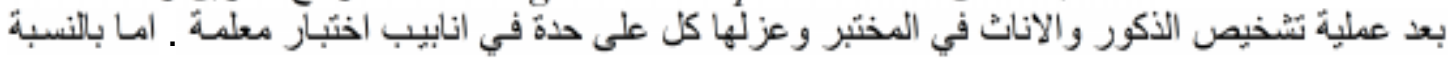

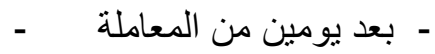

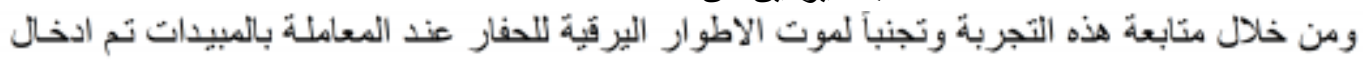

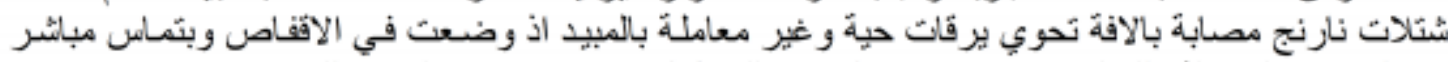

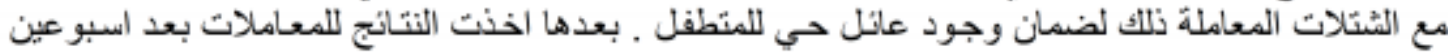

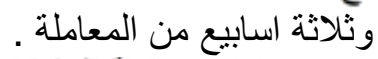

وتُمت دراسة الوفيات للمنّطفل في المكرر ات كلها و المعاملات جميعها وسجلت حالات النطفل

$$
\text { اليرقات الحية في الثتلات . }
$$

\section{النتائج والمناقشة}

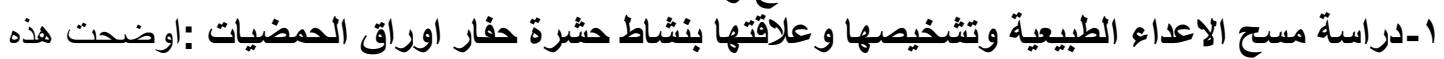

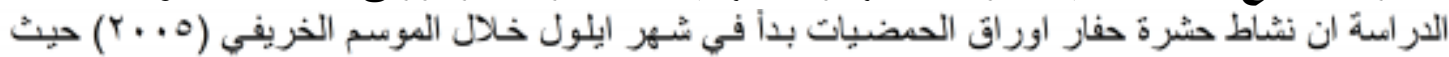

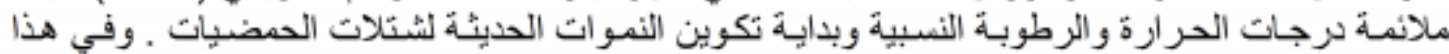

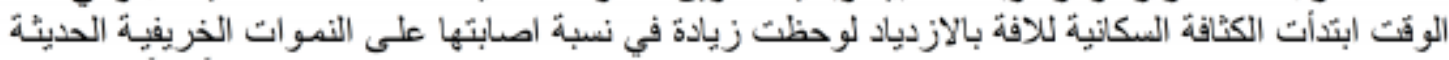

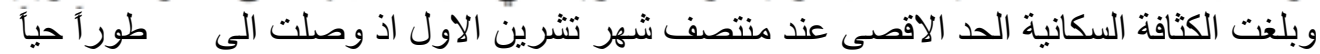

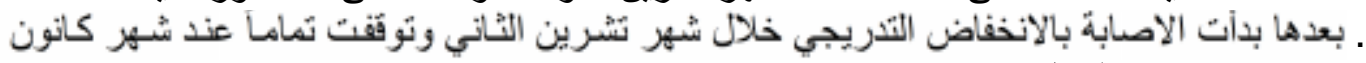

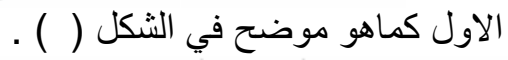

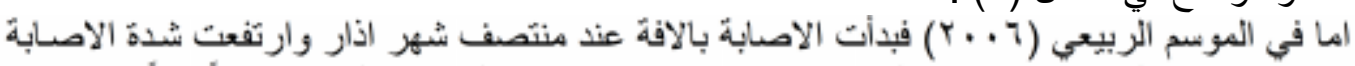

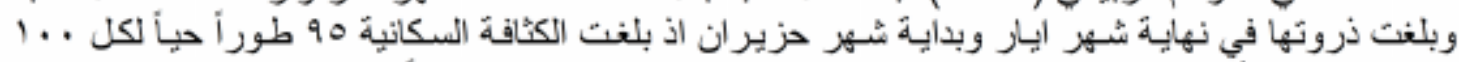

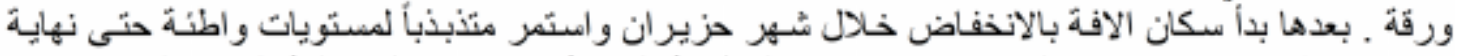

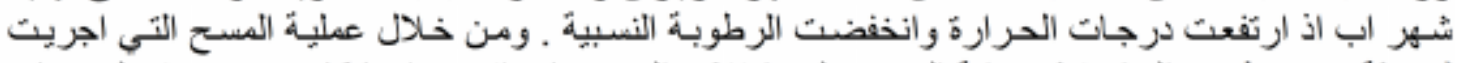

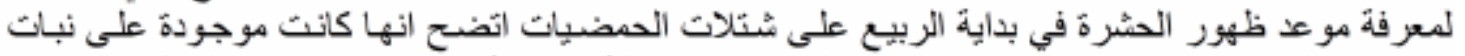

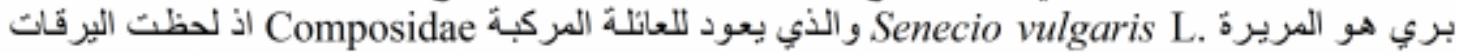
الحية في نهاية الانفاق على اوراق هذا النبات.

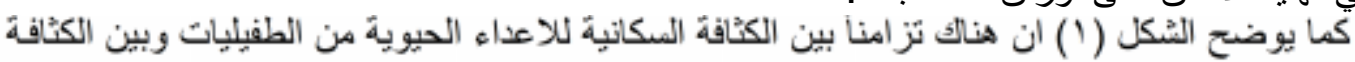

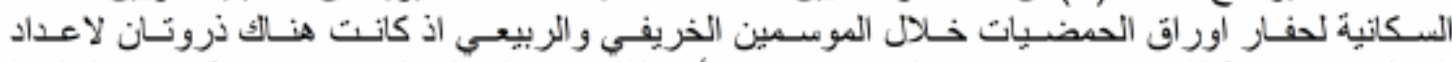

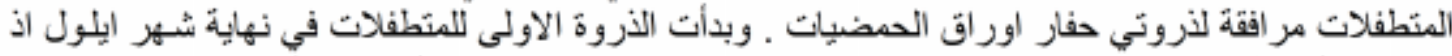

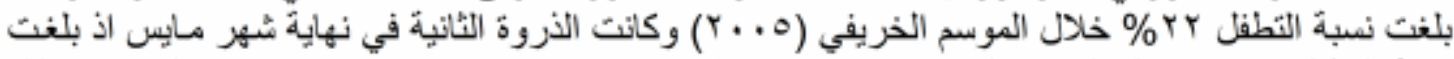

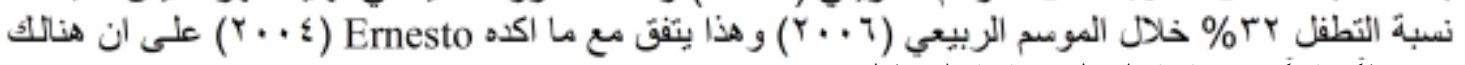

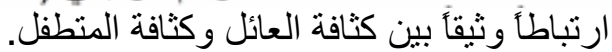

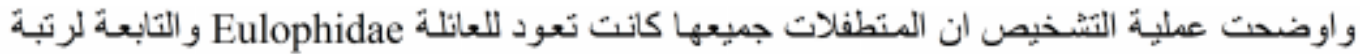

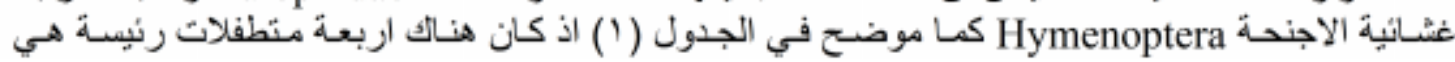
. Baryscapus sp. Penigalio sp. Cirrospilus sp. Ratzeburgiola incompleta وان هذه الطفيليات جميعها تتطفل على الاطوار غير البالغة للافة كاليرقات والعذارى.

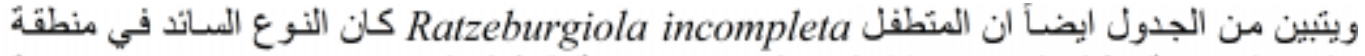

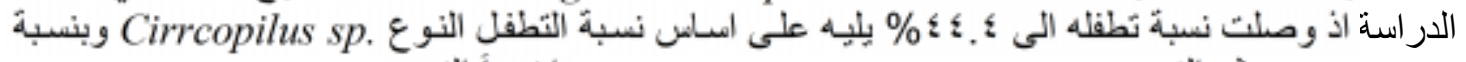

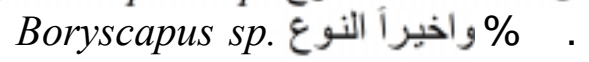

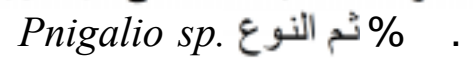
$\%$.

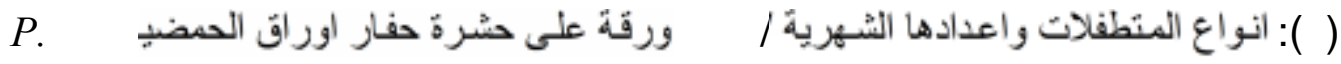
citrella 


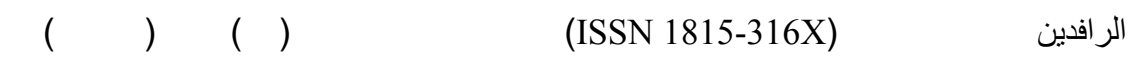

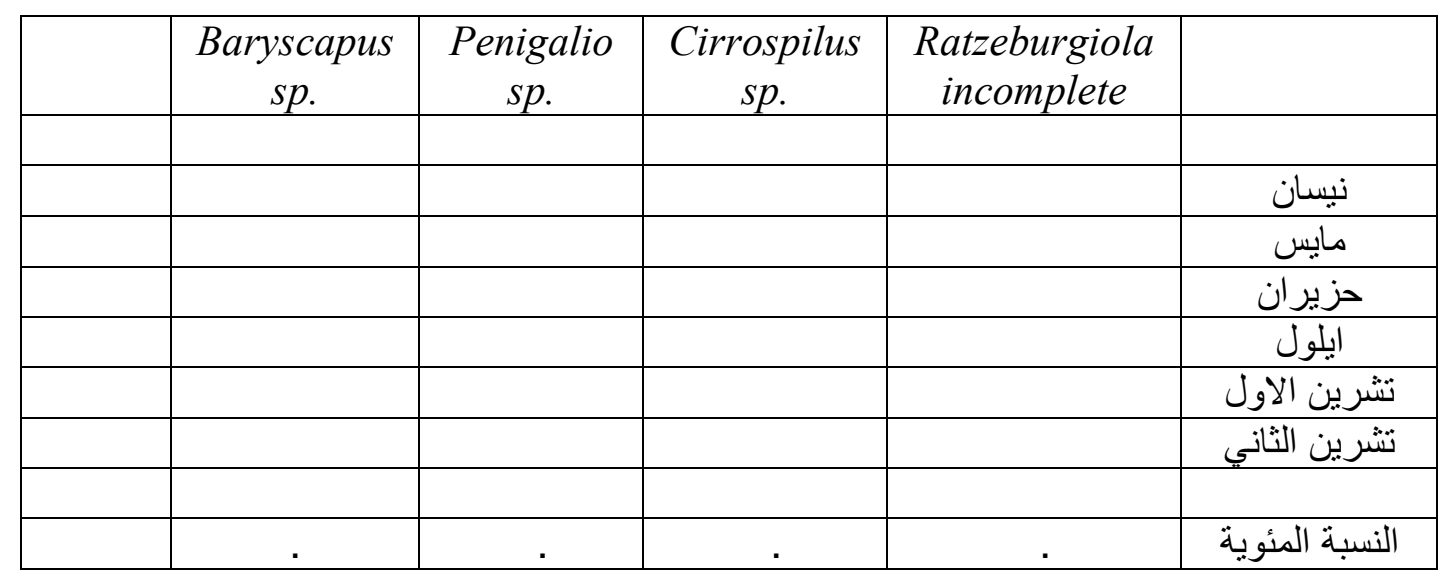

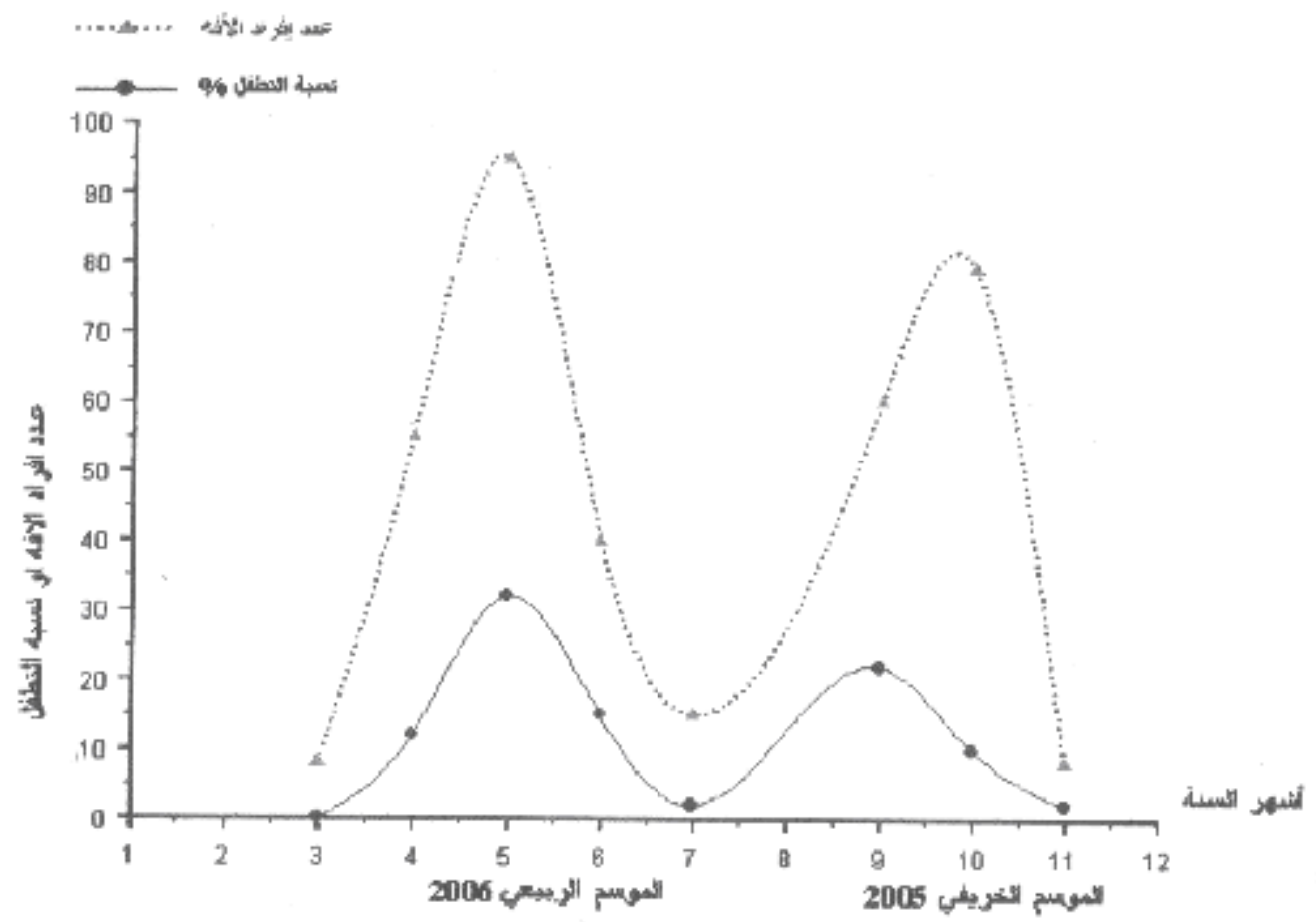

( ) ) : التزامن بين الكثافة السكانية لحشرة حفار اوراق الحمضيات مع الكثافة السكانية لانواع إعناع المتطفلات من اعدائه الحيوية الحية الحفانية

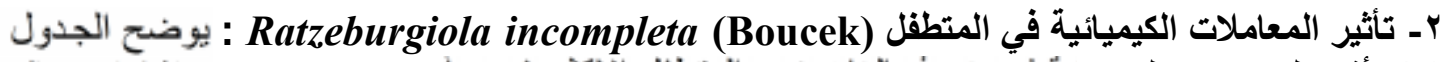

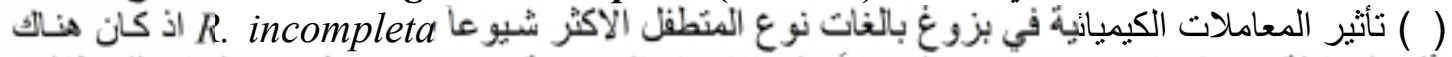

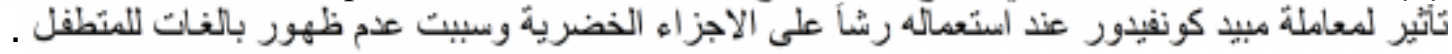

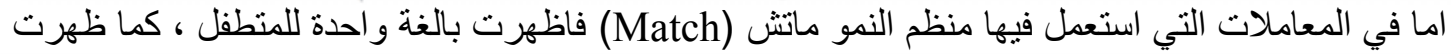

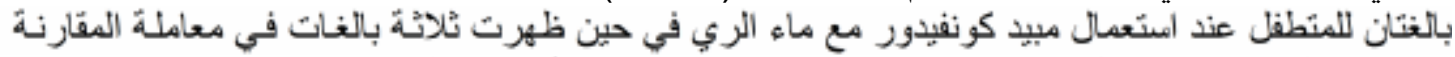

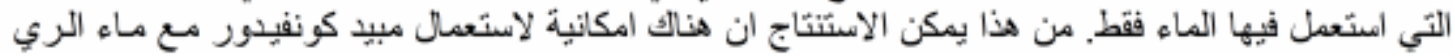




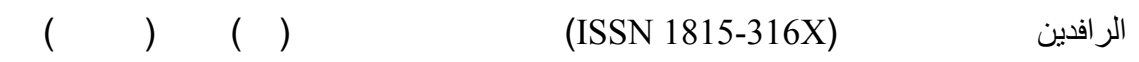

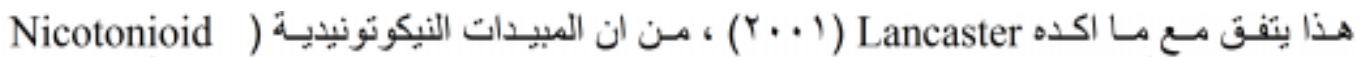

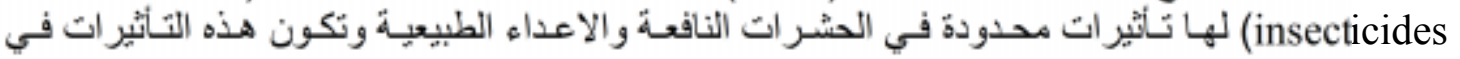

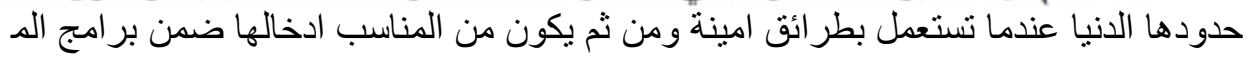

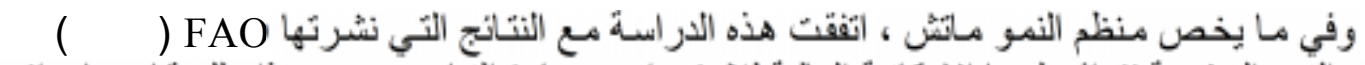

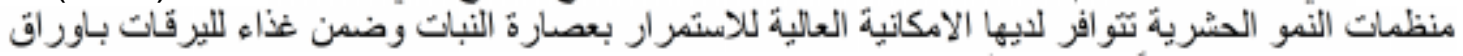

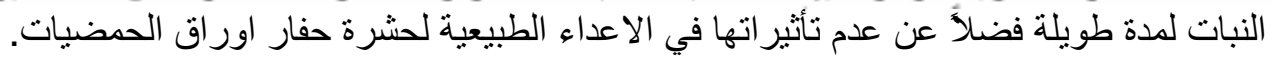

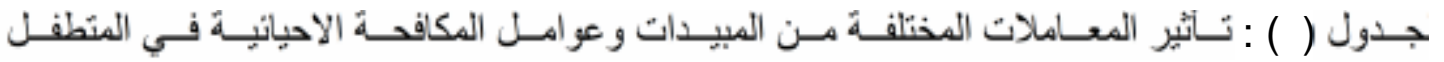
.Ratzeburgiola incompleta

\begin{tabular}{|c|c|c|c|c|}
\hline \multicolumn{4}{|c|}{ عدد بالغات الطفيلي التي ظهرت بعد المعاملات المختلفة } & \\
\hline 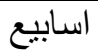 & بعد اسبو عين & بعد يومين & بعد ساعتين & \\
\hline & & & & كونفيدور رشأ على الاوراق \\
\hline & & & & كونفيدور مع ماء الري \\
\hline & & & & \\
\hline & & & & فيرتمك رشأ على الاور اق \\
\hline & & & & ( \\
\hline
\end{tabular}

$$
\text { الاستنتاجات والتوصيات }
$$

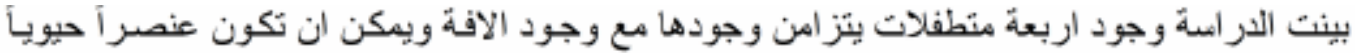

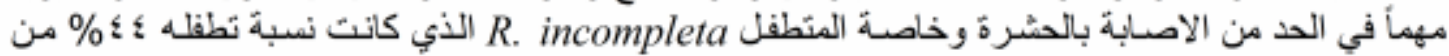

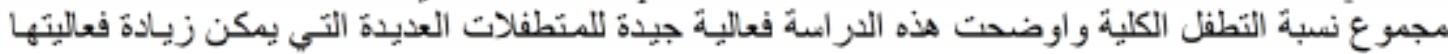

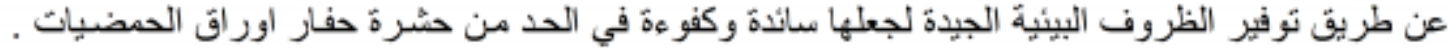

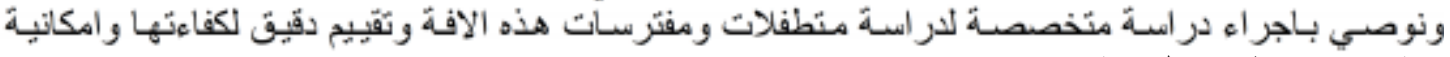
تكثير ها عن طريق التربية .

\title{
STUDY THE ACTIVITY OF SOME PARASITES OF CITRUS LEAFMINER EFFECT OF DIFFERENT CHEMICAL TREATMENTS ON THE EMERGENCE OF THE ADULT PARASITE Ratzeburgiola incompleta (Poueek)
}

Zahraa. A. Al-Ghadhban Khalid M. Al-Adel Radhi F. Al_Jasany

${ }^{*}$ College of Agriculture- University of Baghdad- Plant Protection Department

\begin{abstract}
The survey of parasites showed that there are four parasitoids can be considered as natural enemies of citrus leafminer. All these belong to the family Eulophidae and the order Hymenopter. These parasitoids are Ratzeburgiola incomplete, Cirrospilus sp., Pnigalio sp. and Baryscapus sp. However, the parasitoid $R$. incompleta was the dominant which represents $44.4 \%$ of the total parasitism. A compatible in the time of occurrence between the abundance of the citrus leafminer and the parasitoids was noticed, that is in fall of 2005 the peak of citrus leafminer population density reached the maximum during September with 79 alive stages / 100 leaves and with percentage of parasitism of 22\%. In spring 2006, however, the peak of the pest reached the maximum during May with 95 a live
\end{abstract}




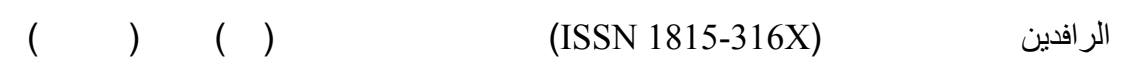

stages / 100 leaves and with percentage of parasitism of $32 \%$.Studying the effect of different chemical treatments on the emergence of the adult parasite $R$. incompleta revealed that confidor soil treatment and the treatment with IGR Match ${ }^{\circledR}$ had the least effect on parasite emergence. Accordingly, these treatments can be considered in applying of IPM to control this pest.

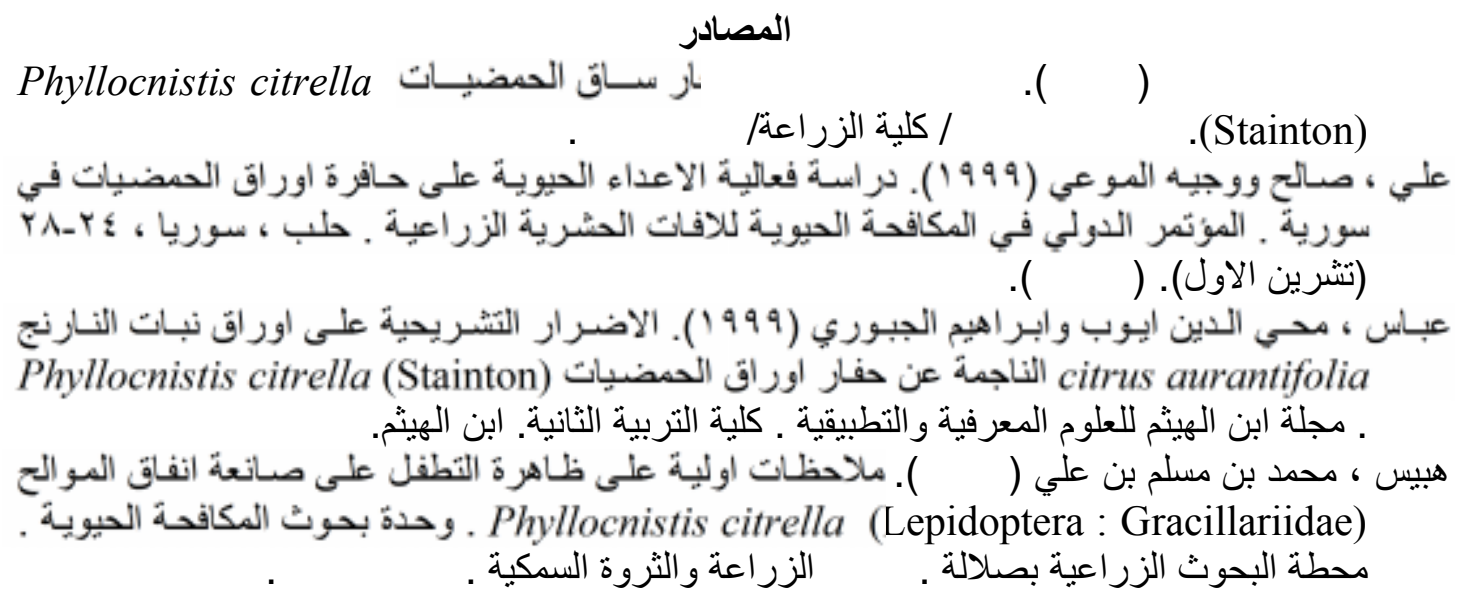

Al-Jboori, I.M.S. Abdul-Rassol and S. J. Saleh (2000). New record of some biological enemies of citrus leaf miner Phyllocnistis citrella Stainton (Lepidoptera : Gracillariidae) in Iraq. accepted for publication in the Bull. Iraq. Nat. Hist. Mus.

David, L. Kerns (2002). Biological Control in Arizona citrus .

Elekcloglu Z. and N. Uygun (2006). Institute of plant protection Adana . Turkey . 2005. The parasitoid complex of citrus leafminer, phyllocnistis citrella stainton (Lepidoptera : Gracillariidae) in the East Mediterranean region of Turkey and their role in biological control , Turk J. Zool. 30 : 155-160

Ernesto, C.B. ; B.M. Nestor ; V.G. Jorge ; C.A.B. Hugo and H. P. Antionio (2004). Instituto Nacional Autonomo de Investigation Agropecuaria Casilla Postal 100 Estacion Experimental Portoviejo - Ecuador . Florida Entomologist 87 (1).

FAO (1996). Report of workshop on citrus leaf miner and its control in the near East, Safita (Tartous), Syria, 30 Sept. 30 Oct. $30: 35$ pp

Lancaster , M. (2001). Actara and Platinum Insecticides. Dept of Entomology , Univ. of Illinois , pp.61-67. 